\begin{tabular}{lr}
\hline \multicolumn{1}{c}{ D Y N A M I C E C O N O M E T R I C } & M O D E L S \\
DOI: http://dx.doi.org/10.12775/DEM.2015.008 & Vol. 15 (2015) 157-165 \\
\hline $\begin{array}{l}\text { Submitted October 24, 2015 } \\
\text { Accepted December 15, 2015 }\end{array}$ & ISSN (online) 2450-7067 \\
\hline
\end{tabular}

Tomasz Groszkowski, Tomasz Stryjewski*

\title{
The Econometric Analysis of Entrepreneurship Determinants in Polish Voivodeships in the Years 2004-2013
}

\begin{abstract}
A b s tract. This article presents research results and describes and clarifies differences in a level of the entrepreneurship index observed between Polish voivodeships in the period from 2004 to 2013. The expected results were confirmed with the fixed effect (FE)/random effect (RE) panel data model. The analysis showed that the level of entrepreneurship varies depending on a voivodeship, and that this differentiation is structural and permanent. The applied model also confirmed the expected determinants of entrepreneurship.
\end{abstract}

K e y w o r d s: entrepreneurship, development factors, panel data model, FE/RE model.

J E L Classification: C23, C26, L26, R12.

\section{Introduction}

Entrepreneurship is undoubtedly one of the fundamental economic development factors, through its influence on development of new products, new markets, creating jobs, and raising the social welfare in general. It is noticeable that some areas are growing fast through establishment of new companies, when others remain far behind. The concept of entrepreneurship is a complex issue, and it is permanently inscribed into different branches of science. A wide range of studies shown that a large and continuously increasing number of classifications and descriptions of entrepreneurship re-

\footnotetext{
* Corresponding author: Tomasz Stryjewski, The University of Computer Science and Economics in Olsztyn, e-mail: tomasz.stryjewski@erbud.pl; Tomasz Groszkowski, The University of Computer Science and Economics in Olsztyn.
}

(C) 2015 Nicolaus Copernicus University. All rights reserved. http://www.dem.umk.pl/dem 
sults in a lack of a uniform theory of entrepreneurship and associated measures, implying possible difficulties in their assessment (Szarecki, 2008, p. 181). Entrepreneurship is multidimensional and consists of many elements that should be considered when determining the characteristics of entrepreneurship (Kalkan, Kaygusuz, 2012).

A management sphere pays particular attention to this aspect, mainly for functional reasons, describing it as the process of organizing and running a business in conditions of risks associated with those activities (Gryffin, 1997, p. 730-731).

Entrepreneurship can therefore be considered as a process creating or identifying opportunities, which later are frequently used regardless of resources possessed at a given time. Entrepreneurship understood this way is a stimulating factor for a creative entrepreneur who finds energy to establish and build a company or organization. Therefore, the entrepreneur is more than just a passive observer of the situation in which he is positioned (Timmons, 1990, p. 5). Entrepreneurship can therefore be described as an organized process consisting of successive phases, occurring in specific conditions and aiming at using innovative ideas to achieve certain benefits, while considering risks involved in this process (Adamczyk, 1995, p. 9-10).

Entrepreneurship is one of the basic factors of economic, social and cultural development. It is associated with activities of different types of businesses, from microenterprises, throughout the whole SME sector, up to large domestic and international enterprises. Certainly, companies play an important role in the Polish and in the European economies. They create a space where human skills and entrepreneurial attitudes are revealed and concentrated. Furthermore, they are a source of innovations and employment. The experience of well-developed countries shows that entrepreneurship plays a significant role in the economy, stimulating economic growth, influencing employment, and providing goods to the market. Therefore, companies are a very important factor for economic growth of a relevant area. Entrepreneurship and businesses are also stimulating factors for growth, and the number of enterprises is frequently considered to be an indicator of economic development.

\section{Entrepreneurship Factors}

Entrepreneurial individuals, stimulated into action in appropriate conditions, establishing businesses, creating new jobs and additional sources of income for themselves and the local population, can be found in every community, also at a local level. 
However, an answer to a question about factors influencing entrepreneurial behavior is not so clear and obvious. In numerous studies on entrepreneurship, selection of factors that affect the level of entrepreneurship is a frequently encountered problem. This article focuses on economic factors, describing the structural and economic determinants of entrepreneurship and quantitative aspects of that issue.

Entrepreneurship is determined by the certain socio-economic and political factors of intensity varying in time and space. Those factors may act in two ways: by bringing positive effects to the economy in form of incentives for business and economic growth stimulators or, on contrary, as means restraining or even inhibiting creation of new and development of already existing business entities. These factors are classified according to various criteria (Chrapek, 2009, p. 321).

Their effects on a recovery of a given area can either be positive or adverse, through their potential to create conditions for formation and development of entrepreneurship. Providing suitable conditions for development of entrepreneurship should therefore be one of the most important priorities for the regional development for authorities at any level (Jezierska-Thole, 2010, p. 129).

Processes associated with entrepreneurial behavior occur in specific socio-economic circumstances. GDP, an economic situation, revenues or investments are just examples of certain macroeconomic indicators affecting development of enterprises.

Considering the entrepreneurship development conditions, it should be noted that every company operates in a certain environment with which it interacts. In entrepreneurial research, one of the common problems is identifying factors determining an entrepreneurial activity. A type of analyzed data, constrained a limitations in very narrow definition of entrepreneurship as the number of formal registered companies.

In this study, it was decided to apply a division into regions defined as established territorial units of a relatively large surface area and population, and with a specific economic policy prevailing.

In Polish economic reality, this region can correspond to a voivodeship. This approach is based on factors including their independently established policies, independent local authorities, and own budget. With specifics of each voivodeship, an endogenous development potential can be developed, influencing opportunities and barriers to the development and growth of enterprises in that region.

According to the subject of this article, individual features of the region, having a direct influence on the investment level and the profitability of the 
business should be emphasized (Godlewska, 2001, p. 14). If the region is understood as an environment consisting of humans, other companies and institutions, having certain features that may or may not be attractive to new businesses, then it is important to communicate conditions prevailing in that region, which will affect the company's position, and to ensure future entrepreneurs are familiar with and have access to that information.

\section{Research Methodology and Analysis Results}

In this paper, the main part of the space-time analysis of entrepreneurship in Poland aimed at finding information about factors determining specific indicators, and reasons why these indicators vary in individual voivodeships. A panel approach of the fixed effect/random effect (FE/RE hereafter) type is suitable for such kind of modeling (Greene, 2005).

The analysis covered annual data for a period from 2004 to 2013 for 16 Polish voivodeships. 15 factors possibly affecting the entrepreneurship development in Poland ${ }^{1}$ were selected, following a detailed substantive analysis: Gross Domestic Product per capita (GDP per capita), enterprises investment outlays per capita (inv), retail sales per capita (sprzed), new apartments put in use per thousand inhabitants (mieszk), population density (gest), percentage of population living in cities (urbanizacja), number of cities in a region (miasta), roads outside built-up areas per $100 \mathrm{~km} 2$ (drogi), employment rate (zatr), average monthly disposable income per capita (doch), number of tourist facilities per capita (turyst), number of people with higher education per thousand inhabitants (wykszt), net migration per thousand inhabitants (migr1000), and municipal revenues per capita (doch per capita).

Starting with a framework of the congruent modeling concept, an internal structure of specific processes was analyzed during the first stage of the study (Talaga, Zieliński, 1989). A congruent panel data model exhibits the same harmonic structure on both sides of the equation in dynamic terms. The analysis showed the significance of a linear trend in all tested processes and autoregressive relationships over time. However, due to a small sample size in the researched period, only the first-order autoregression was considered.

The main problem associated with the use of models of this class is that they belong to a group of static methods. Modeling the dynamic relationship with these methods results in both OLS and GLS coefficients bias (Wooldridge, 2010).

\footnotetext{
${ }^{1}$ Understood as the number of companies per 10000 people of employable age (entrepreneurship index - wskpz).
} 

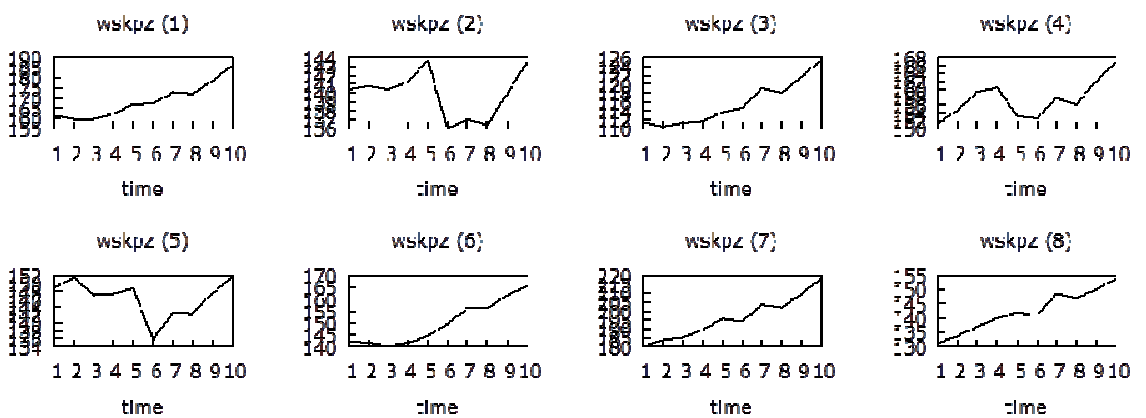

Ime

time

$=\operatorname{lm} e$
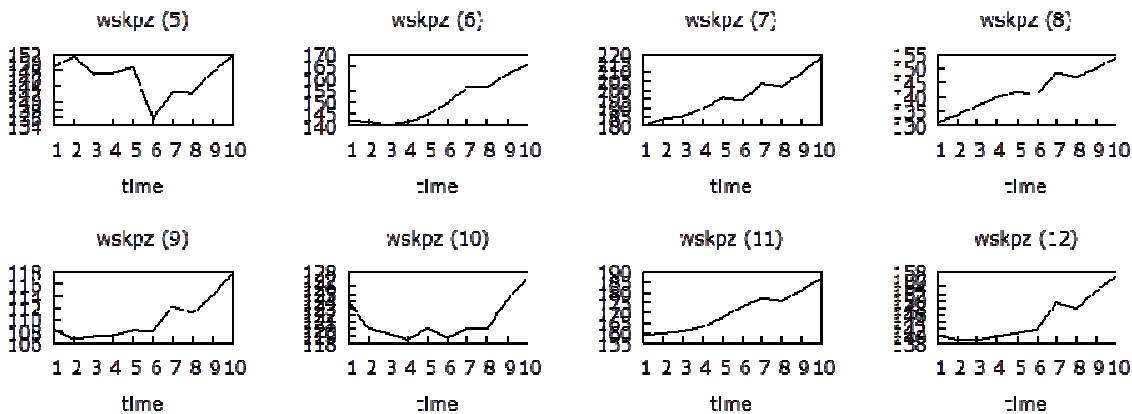

wskpz (13)
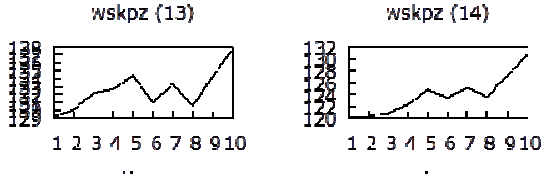

-Ime
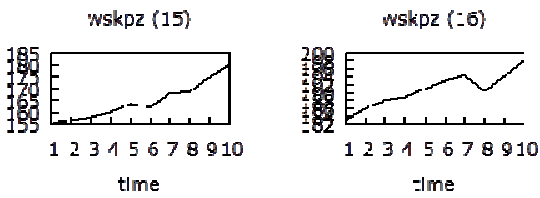

Figure 1. Entrepreneurship index - time series for voivodeships in the years 2004-2013

Unfortunately, dynamics of all processes exhibits strong autocorrelation (in terms of ACF and PACF functions). Since use of a lagged dependent variable is not allowed in the FE/RE models, it was necessary to select an appropriate instrumental variable, so no information was lost. It should be noted that the search for an instrument within a specified group of variables did not give any meaningful results. Therefore, it was necessary to create an "artificial" variable corresponding to a character of the real instrument.

An instrumental variable for the entrepreneurship indicator was evaluated with a dynamic panel model based on a structure of internal variables (model hypothesis):

$$
w s k p z_{i t}=\alpha_{0}+\alpha_{1} w s k p z_{i, t-1}+\alpha_{2} w s k p z_{i, t-2}+\alpha_{3} t+\eta_{i t}
$$

where: $w s k p z_{i t}$ - spatial entrepreneurship indicator in period t, $t$ - linear trend, $\alpha_{0}, \alpha_{1}, \alpha_{2}, \alpha_{3}$ - evaluation parameters, $\eta_{i t}$ - random spatial compo- 
nent in period $t$. The following model was developed with a two-step estimation method ${ }^{2}$ (2-step method).

Table 1. A dynamic panel model for a spatial entrepreneurship indicator (Blundell and Bond estimator)

\begin{tabular}{cccccc}
\hline & \multicolumn{5}{c}{ Dependent variable: wskpz } \\
\cline { 2 - 5 } & Coefficient & SD & z & $p$-value & \\
\hline wskpz(-1) & 0.9835 & 0.0385 & 25.5764 & $<0.00001$ & $*$ \\
Const. & 1.4756 & 5.0447 & 0.2925 & 0.7699 & \multirow{2}{*}{ *** } \\
Time & 0.4533 & 0.1128 & 4.0188 & 0.00006 & ${ }^{*}$ \\
\hline \multicolumn{5}{c}{ Sargan over-identification test: } & Test for AR(1) errors: $z=-2.27161[0.0231]$ \\
\multicolumn{5}{c}{ Chi-square(43) $=15.7061$} & Test for AR(2) errors: $z=-0.713604[0.4755]$ \\
\hline
\end{tabular}

The fitted values from the above model created an instrumental variable for a dynamic relationship in FE/RE models.

Further research focused on identifying determinants for the spatial entrepreneurship indicator and its spatial differentiation described by a neighborhood matrix. For this purpose, a group of potential exogenous variables was determined and a pooled OLS model was estimated. Results of this estimation are shown in Table 2 (only statistically significant variables). The next step of the analysis was verification which approach is correct: pooled OLS or FE/RE. Results of this verification are shown in Table 3.

Table 2. The data panel model estimation using pooled OLS

\begin{tabular}{|c|c|c|c|c|c|}
\hline \multicolumn{6}{|c|}{ Dependent variable: wskpz } \\
\hline & Coefficient & $\mathrm{SD}$ & t-ratio & $p$-value & \\
\hline Const. & 4.6527 & 3.59303 & 1.2949 & 0.1978 & \\
\hline urbanizacja & -16.5172 & 4.61591 & -3.5783 & 0.0005 & $* * *$ \\
\hline turyst(-1) & 0.0625 & 0.0300 & 2.0804 & 0.0396 & $* *$ \\
\hline doch per capita & 0.0090 & 0.0018 & 4.9687 & $<0.00001$ & $* * *$ \\
\hline Time & -0.4339 & 0.1932 & -2.2453 & 0.0266 & ** \\
\hline yhat17(-1) & 0.9631 & 0.0297 & 32.3751 & $<0.00001$ & *** \\
\hline \multicolumn{2}{|c|}{ Mean dependent var } & 149.7844 & \multicolumn{2}{|c|}{ S.D. dependent var } & 25.9606 \\
\hline \multicolumn{2}{|c|}{ R-squared } & 0.9824 & \multicolumn{2}{|c|}{ Adjusted R-squared } & 0.9817 \\
\hline \multicolumn{2}{|c|}{ Log-likelihood } & -339.4414 & \multicolumn{2}{|c|}{ Akaike criterion } & 690.8827 \\
\hline \multicolumn{2}{|c|}{ Schwarz criterion } & 707.9949 & \multicolumn{2}{|c|}{ Hannan-Quinn } & 697.8355 \\
\hline \multicolumn{2}{|c|}{ rho } & 0.3696 & \multicolumn{2}{|c|}{ Durbin-Watson } & 1.0856 \\
\hline
\end{tabular}

Note: That 17 - instrumental variable from table 1 model.

\footnotetext{
${ }^{2}$ See footnote 1 .
} 
Table 3. Panel models diagnostics ${ }^{3}$

\begin{tabular}{|c|c|c|}
\hline \multicolumn{3}{|c|}{$F$ test (Fixed effect) } \\
\hline $\begin{array}{l}\text { the null hypothesis that the } \\
\text { pooled OLS model } \\
\text { is adequate, in favor of the fixed } \\
\text { effects alternative }\end{array}$ & $F(15,107)=2.6292$ & $p$-value $=0.0021$ \\
\hline \multicolumn{3}{|c|}{ Breusch-Pagan test (Random effect) } \\
\hline $\begin{array}{l}\text { the null hypothesis that the } \\
\text { pooled OLS model } \\
\text { is adequate, in favor of the } \\
\text { random effects alternative }\end{array}$ & $L M=1.7714$ & $\begin{array}{c}\mathrm{p} \text {-value }=\text { prob }(\text { chi-square }(1)> \\
1.77137)=0.1832\end{array}$ \\
\hline \multicolumn{3}{|c|}{ Hausman test } \\
\hline $\begin{array}{l}\text { the null hypothesis that the } \\
\text { random effects } \\
\text { model is consistent, in favor of } \\
\text { the fixed effects model }\end{array}$ & $H=14.5289$ & $\begin{array}{c}p \text {-value }=\text { prob }(\text { chi-square }(5)> \\
14.5289)=0.0126\end{array}$ \\
\hline
\end{tabular}

Results presented in Table 3 imply that a fixed effects-FE model is an appropriate approach. This means that the spatial differentiation in the entrepreneurship index level is of a structural and permanent character.

Therefore, the next step of the study was to estimate and validate the FE model. The model presented in Table 2 became a model hypothesis and the estimated (after verification) FE model is presented in Table 4.

Table 4. The FE model (Dependent variable: wskpz) - LSDV estimator

\begin{tabular}{cccccc}
\hline & Coefficient & SD & t-ratio & p-value & \\
\cline { 2 - 4 } Const & 31.9812 & 9.3363 & 3.4255 & 0.00086 & $*$ \\
doch per capita & 0.0091 & 0.0017 & 5.4573 & $<0.00001$ & ${ }^{* * *}$ \\
yhat17(-1) & 0.7004 & 0.0728 & 9.6190 & $<0.00001$ & ${ }^{* * *}$ \\
\hline Mean dependent var & 149.7844 & S.D. dependent var & 25.9606 \\
Sum squared resid & 1127.241 & S.E. of regression & 3.2012 \\
LSDV R-squared & 0.9868 & Within R-squared & 0.7427 \\
LSDV F(17, 110) & 484.8430 & P-value(F) & $4.79 \mathrm{e}-95$ \\
Log-likelihood & -320.8560 & Akaike criterion & 677.7120 \\
Schwarz criterion & 729.0486 & Hannan-Quinn & 698.5703 \\
Rho & 0.2742 & Durbin-Watson & 1.1935 \\
\hline
\end{tabular}

The FE model has better statistical properties than the model estimated by pooled OLS. In particular, significant reduction in the first-order random component autocorrelation was possible in the FE model. However, the study also showed that the analysis of the entrepreneurship spatial differentiation using the spatial entrepreneurship indicator is biased and, in conse-

\footnotetext{
${ }^{3}$ See footnote 1 .
} 
quence, has some disadvantages. Particularly, this indicator is strongly autoregressive, indicating an autonomous nature of changes in that process. It may also imply that variables used in the analysis were unsuitable.

However, the results presented in Table 4 confirm the economic theory about the entrepreneurship development index. The main determinants of entrepreneurship remain the same, being the entrepreneurship indicator from the previous period and the municipal revenues per capita. These two variables positively influence the entrepreneurship rate, although they strengthen the autoregressive character of that process.

\section{Conclusions}

A study on entrepreneurial activities based on their index led to three main conclusions.

First, the analysis showed that the problem of entrepreneurship development in Poland is a structural problem. This means that differences in the levels in individual regions are stable and result from internal conditions, as well as from the regional polarization processes. Therefore, this problem cannot be solved locally, but only as part of a coherent regional policy at the governmental or European level.

Second, the entrepreneurship index determinants in the studied period were identified. The main determinant is the municipal revenues per capita. However, the entrepreneurship index is a strongly autonomous variable and, therefore, the autoregressive component is important in the analyzed model. The main causes of the dependent variable formation are the regional economic situation (autoregressive process) and public revenues. Public revenues affect the dependent variable in two ways: as a determinant (indicator) of regional economic situation and as the basis for public expenditures which, in turn, influence small local enterprises.

Third, an important part of the study is focusing on a selection of suitable explanatory variables. The spatial entrepreneurship indicator is highly autocorrelated, and this causes problems with identification of its determinants. In the further research, other measures should be considered for exploration and selection, better describing the investigated process.

\section{References}

Adamczyk, W. (1995), Ewolucja form i typów przedsiębiorczości (The evolution of forms and types of entrepreneurship), Zeszyty Naukowe Akademii Ekonomicznej w Poznaniu, 236. 
Chrapek, G. (2009), Przedsiębiorczosśc osób fizycznych na obszarach wiejskich Podkarpacia, [w:] Rola przedsiębiorczości w ksztattowaniu spoteczeństwa informacyjnego (Entrepreneurship individuals in rural areas of Podkarpacie, [in:] the role of business in shaping the information socjety), Seria Przedsiębiorczość - Edukacja, WarszawaKraków.

Godlewska, H. (2001), Lokalizacja działalności gospodarczej (The location of economic activity), Dom Wydawniczy ELIPSA, Warszawa.

Greene, W. H. (2005), Econometric Analysis, Prentice Hall, New York.

Gryffin, R. W. (1997), Podstawy zarzadzania organizacjami (Fundamentals of organizational management), PWN, Warszawa.

Jezierska-Thole, A. (2010), Zmiany poziomu infrastruktury i jej wpływ na rozwój przedsiębiorczości na obszarach wiejskich na przykładzie województwa kujawskopomorskiego i pomorskiego (Changes in the level of infrastructure and its impact on development of entrepreneurship in rural areas on the example of KujawskoPomorskie and Pomorskie), Acta Acientum Polonorium, Oeconomia, 9(3).

Kalkan, M., Kaygusuz, C. (2012), The Psyhology of Enterpreneurship [in:] Entrepreneurship - Born, Made and Educated, Ed. T. Burger-Helmchen, Rijeka.

Szarecki, A. (2008), Przedsiębiorczość jako forma kultury (Entrepreneurship as a form of culture), Problemy Zarzadzania, 2.

Talaga, L., Zieliński, Z. (1986), Analiza spektralna w modelowaniu ekonometrycznym (Spectral analysis in econometric modeling), PWN, Warszawa.

Timmons, J. (1990), New Venture Creation, Irvin, Boston.

Wooldridge, J. M. (2010), Econometric analysis of cross section and panel data, Massachusetts Institute of Technology.

\section{Ekonometryczna analiza determinant przedsiębiorczości w Polskich województwach w latach 2004-2013}

Z a r y s t r e ś c i. W artykule przedstawiono wyniki badań, opisujące i wyjaśniające różnice w poziomie wskaźnika przedsiębiorczości pomiędzy województwami polski w latach 2004 -2013. W celu potwierdzenia zakładanych rezultatów, użyto modelu panelowego z efektami stałymi i losowymi. Analiza wykazała, że wskaźnik przedsiębiorczości jest zróżnicowany pomiędzy województwami, a zróżnicowanie to ma charakter strukturalny i stały. Model potwierdził również oczekiwane determinanty przedsiębiorczości.

S łow a kluczowe: przedsiębiorczość, czynniki rozwoju, model panelowy, model $\mathrm{FE} / \mathrm{RE}$ 
